\title{
An Assessment of Financial and Economic Feasibility of Selected Forest Plantation Species
}

\author{
G.H. Pitigala and H.M. Gunatilake*
}

\begin{abstract}
The forest cover of the country has declined significantly and the remaining natural forests provide valuable environmental services. Since logging reduces the supply of environmental services, alternative sources of timber play an important role in sustainable management of forestlands. Forest plantations are alternatives to logging natural forests for timber and other wood products. The objective of this study is to examine the financial and economic feasibility of selected forest plantation species. According to the study, at a 10\% discount rate, Mahogany, Teak, Jak and Eucalyptus result in positive financial NPVs. At higher discount rates, all considered species result in negative financial NPVs. Teak provides the highest financial NPV. In a social context, when environmental services are incorporated, Mahogany, Teak, Jak, Eucalyptus and Pine yield higher economic NPVs at 6\% social discount rate. This shows that there is a divergence between financial and economic returns to forest plantations. Therefore, government interventions are necessary to get the private sector involved in plantation forestry.
\end{abstract}

\section{Introduction}

Forests were once looked upon as a storehouse of timber and as unused lands available for development. Now their intrinsic values and environmental services are widely appreciated. They provide the habitat for flora and fauna, provide recreational facilities, protect watersheds, act as store of carbon dioxide and are responsible for micro climatic stabilization. Forest conservation is necessary to supply the above services because harvesting a forest for timber reduces most of these services. Thus, timber supply and other forest services compete with each other. One of the important dilemmas the forestry sector faces today is reconciling these two requirements, which appear to be in conflict with each other. Natural forests of the country

The authors are, respectively, Final Year Undergraduate Student at the time the study was conducted, and Head, Department of Agricultural Economics, University of Peradeniya. 
will not be able to sustain increasing demand for wood and wood products (MFE, 1995). Therefore, we must move towards alternative sustainable wood production systems on a more limited land area.

Sri Lanka underwent rapid deforestation that reduced the natural forest cover to about $22 \%$ of the land area. Currently, non-forest lands such as homegardens, coconut lands, rubber lands etc. are believed to supply a major portion of saw logs in Sri Lanka. According to an estimate made in late 1980, natural forests supply only about $22 \%$ of the timber while homegardens supply over $40 \%$ (MFE, 1995). These figures should be read with some care as illegally extracted timber from natural forests is also recorded under the homegarden category. Contribution to timber supply from natural forests may be much higher than indicated in the figure when illegal timber is included. Having reviewed the future supply and demand scenario, MFE (1995) has forecasted a shortage in timber supply if the current trends are allowed to continue (see Figure 1). Figure 1 clearly shows the widening gap between saw log production and consumption. Such a gap will increase incentives for illegal logging from natural forests and may seriously affect forest conservation efforts. Plantation forestry can play a significant role in resolving this issue.

Figure 1: $\quad$ Predicted sawn wood production and consumption for Sri Lanka.

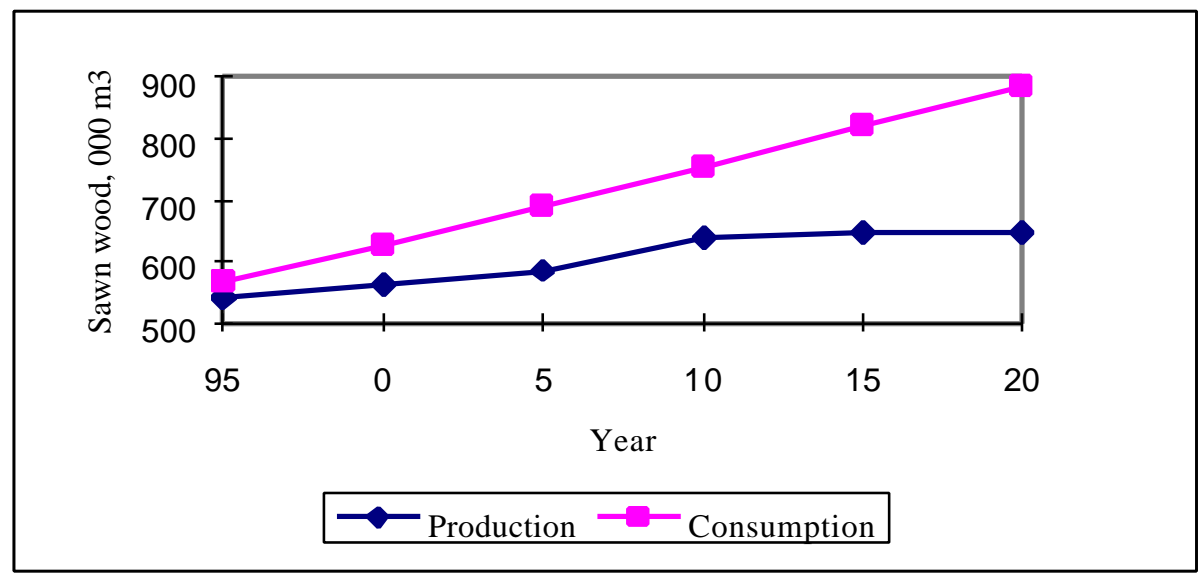

(Source: MFE,1995) 
In addition to establishment of forest plantations, enhancing wood production in home gardens, importation of timber and improving technical efficiency in sawmilling are alternatives for harvesting timber from natural forests. This paper deals with the financial and economic feasibility of forest plantations. Properly managed forest plantations can produce very high yields of high quality wood. Because of the high yields per unit area, the area affected is smaller and concentrated, leaving more room for other types of land uses. Also, tree planting will encourage rehabilitation of degraded natural forestlands. In addition, well established forest plantations will act as a Carbon sink and provide watershed benefits in terms of regulation of water flow, control soil erosion, etc.

Currently about $94 \%$ of the total forest plantation area belongs to the Department of Forest Conservation. Private sector does not play any significant role in forest plantation at present. As in many other countries, state owned forest plantations are operating sub-optimally due to low survival rates, insufficient maintenance, encroachment, losses due to fire, low annual planting rates and excessive cost of management. Involvement of the private sector in forest plantation management can eliminate most of these inefficiencies. Natural factors like climate and soil will determine the growth and production of the selected species for forest plantations, while economic factors will determine the financial limits in planning the forestry activities. Private sector investors always have investment alternatives and wood production still has to demonstrate its potentials as a viable investment in Sri Lanka. Therefore, the objectives of the study were to assess the profitability of forestry as a land use and investment alternative for individuals and to the society as a whole.

\section{Methodology}

The study considers five mostly cultivated commercial timber cultivars. Therefore, Teak (Tectona grandis) was assumed to be established in the dry zone on a 21 year rotation period. Jak (Artocarpus heterophillus), Eucalyptus (Eucalypts grandis) and Mahogany (Swetenia macrophilla) were assumed to be established in the intermediate wet zone for 40, 25 and 30 year rotation periods, respectively. Pine (Pinus caribea) was assumed to be established in up country wet zone for a 20 year rotation period. Financial and economic analyses were carried out to examine the financial and economic feasibility of these species. 
Considering the private objective of profit maximization, the costs and benefits incurred by the investor were identified and valued using the market prices on a per hectare basis. The data used in the financial analysis is summarized in Table 1. The Forest Department (FD) norms were taken for assessing the costs of establishment and maintenance of forest plantations. State timber corporation prices were used for valuing the final timber harvest. Only $\log$ and fuelwood assortments were considered as returns. Inflation was tackled by considering the constant prices in valuation, since it affects only the price level and does not affect the real value of the resources. For the analysis, year 2000 prices were used considering it as the base year. Four percent of the undeveloped land value, evaluated by the Valuation Department under the land lease out scheme implemented by the FD, was considered as the annual rental payment for land. For the financial net benefit stream, discount rates of $10 \%, 15 \%, 20 \%$ and $30 \%$ were considered. In the financial analysis high discount rates were used because the individual time preference is greater than the society's time preference.

In Sri Lanka, in the presence of various taxes, subsidies, and other distortions plus the lack of institutions required by the market economic system, there is no reason to believe in a perfect market (Gunatilake, 1998). In such situations shadow prices, which are more close to the true willingness to pay or accept are used. Therefore the market prices used in the financial analysis were corrected to shadow prices using the appropriate conversion factors. The conversion factors developed by The National Planning Division of the Ministry of Policy Planning and Implementation were used in the economic analysis. Table 2 shows the conversion factors used in the economic analysis. In the economic analysis the average undeveloped land values for different regions were used. Annual rental payments were considered as transfer payment and thus ignored in the economic analysis. The National Planning Division of the Ministry of Policy Planning and Implementation has suggested a $6 \%$ discount rate as the social time preference; thus it is used in the economic analysis. 
Table 1: $\quad$ Summary data used in financial analysis

\begin{tabular}{|c|c|c|c|c|c|}
\hline & Year & $\begin{array}{l}\text { Thinning } \\
\text { yield } \\
\left(\mathrm{m}^{3} / \mathrm{ha}\right)\end{array}$ & $\begin{array}{c}\text { Mean } \\
\mathrm{dbh}^{\mathrm{a}}(\mathrm{cm})\end{array}$ & $\begin{array}{l}\text { Log price } \\
\text { (Rs/m3) }\end{array}$ & $\begin{array}{l}\text { Fuelwood price } \\
\text { (Rs/m3) }\end{array}$ \\
\hline \multirow[t]{2}{*}{ Mahogany } & 20 & 35 & 11 & 11000 & 350 \\
\hline & 30 & 65 & 20 & 20000 & 350 \\
\hline \multirow[t]{3}{*}{ Teak } & 7 & 10.4 & 10 & 6600 & 450 \\
\hline & 14 & 19.5 & 15 & 7000 & 450 \\
\hline & 21 & 27 & 19 & 12850 & 450 \\
\hline \multirow[t]{4}{*}{ Eucalyptus } & 7 & 21.4 & 10 & 2600 & 400 \\
\hline & 13 & 28.6 & 17 & 2600 & 400 \\
\hline & 18 & 61.5 & 24 & 3950 & 400 \\
\hline & 25 & 303 & 40 & 7900 & 400 \\
\hline \multirow[t]{3}{*}{ Jak } & 20 & 114.8 & 85 & 6750 & 400 \\
\hline & 30 & 159.1 & 100 & 10250 & 400 \\
\hline & 40 & 170.85 & 105 & 12600 & 400 \\
\hline \multirow[t]{4}{*}{ Pine } & 6 & 10.5 & 9 & 9000 & 350 \\
\hline & 11 & 49 & 16 & 16000 & 350 \\
\hline & 16 & 56 & 22.5 & 22500 & 350 \\
\hline & 20 & 59 & 28 & 28000 & 350 \\
\hline
\end{tabular}

a) dbh is the diameter at basal height. The log price is mainly based on dbh. For the analysis, mean values for dbh given in the Forestry Sector Master Plan (1995) were considered.

Although quantification of most of the environmental benefits is difficult due to lack of data, incorporating the quantifiable environmental benefits and costs in the analysis provide better guidelines in evaluating a project. Therefore, Carbon sequestration benefits and the watershed benefits of forest plantations were considered in the analysis. However, these benefits are realized by society and not by the private investor. Therefore they were ignored in the financial analysis and evaluated and incorporated in the economic analysis.

Annual Carbon sequestrations in Teak plantations in Sri Lanka has been evaluated by Abayasiri and Ranasinghe (2000). Since these data were not available for other species, the average annual Carbon sequestration estimated for tropical rainforests were used for them. The potentials to absorb $\mathrm{CO}_{2}$ by tropical 
moist rainforests may vary from 6 to the total land area. The 16 tones per ha per year intergovernmental panel on climate (Abeygunewardena et al., 1999). Fast change has developed valuation growing plantation tree species can tables to assess economic benefits sequest more carbon compared to from carbon sequestration. These slow growing natural forests. But in values are shown in table 3. Average this analysis it is assumed that only value for the time period 2001 to 10 tons of carbon can be absorbed 2030 of US\$ 14 was used in the annually because part of the rotation analysis.

period may not have green cover in

Table 2: $\quad$ Conversion factors used in the economic analysis

\begin{tabular}{lc}
\hline Sector & Conversion factor \\
\hline Scarce labour & 0.785 \\
Infrastructure & 1.115 \\
Equipment & 0.776 \\
Average conversion factor & 0.875 \\
\hline
\end{tabular}

Source: Ministry of Policy Planning and Implementation of Sri Lanka (1999)

Table 3: $\quad$ Estimated average carbon sequestration benefits of tropical rain forests

\begin{tabular}{lc}
\hline Time Period & Value in US\$ \\
\hline $1991-2000$ & $7.85-17.66$ \\
$2001-2010$ & $8.64-19.43$ \\
$2011-2020$ & $8.90-20.03$ \\
$2021-2030$ & $8.89-20.00$ \\
\hline
\end{tabular}

Source: Abeygunewardena et al., 1999 
Ruitenbeek (1989) has evaluated the annual flood control forest services to be US\$ 2.3/ha. He has valued flood protection based on the expected value of loss of paddy yield per hectare from flooding in one year assuming the forest to disappear (Emmanul et al., 1995). Total cost of sedimentation in the Mahaweli reservoir has been evaluated by Gunatilake and Gopalakrishnan (1999) to be US\$ 4.42 per ha. This value includes irrigable area loss, hydropower production loss, cost of water purification and fisheries yield loss. An assessment of on-site and off-site costs of soil erosion in the upper Mahaweli watershed has been evaluated by Gunatilake and Gunawardena (2000). Since this analysis considers degraded lands for forest plantations, the onsite cost of soil erosion in the upper Mahaweli watershed for degraded grassland of US\$ 3.75 per ha was considered. Therefore, the total watershed protection benefits have been evaluated to be US\$ 6.37 per ha per annum. Table 4 shows the average soil erosion rates for different land uses, which were considered in the calculations.

A sensitivity analysis was carried out to assess the stability of the project subjected to various changes in cost and benefit structure. Here, $10 \%$ increase in land prices, $10 \%$ increase and $10 \%$ decrease in total costs were considered. The situation, if highly productive lands were used,

Table 4: $\quad$ Average soil erosion rates for different land uses

\begin{tabular}{lc}
\hline Land use & Soil erosion rate $(\mathrm{t} / \mathrm{ha})$ \\
\hline Pine & 10.0 \\
Eucalyptus & 12.0 \\
Teak & 8.0 \\
Mahogany & 8.0 \\
Poor Quality plantations & 15.0 \\
Open land & 25.0 \\
\hline
\end{tabular}

Source: MFE (1995) 
was also assessed assuming a 10\% increase in total yields simultaneously with a $10 \%$ increase in land values.

\section{Results and Discussion}

This presents the financial net present values at $10 \%, 15 \%, 20 \%$ and $30 \%$ discount rates and internal rate of return (IRR) for the different species considered. The net present value determines the present value of the net benefits by discounting the stream of net benefits back to the beginning of the base year. IRR is defined as the rate of return on the investment that equates the present value of benefits and costs (Hufschmidt and Dixon, 1986).

Table 5 shows that Teak, Mahogany, Eucalyptus, Jak and Pine provide positive net present values at a $10 \%$ discount rate. Among the considered species Teak provides the highest NPV. The above results indicate that the benefits of the project are not very stable when discount rates change. In such situations, sensitivity analysis provides better insights to the analysis. The IRR values show that they generally exceed the borrowing rate of $12 \%$. However, the IRR values of forest plantation species should be compared with that of the competing alternative land uses in order to understand the strength of the forest plantations as investment opportunities for the private sector.

Table 6 shows that at a $10 \%$ cost increase, NPV for all considered species tends to decrease. Pine without resin tapping results in a negative NPV even at a $10 \%$ discount rate.

Table 5:

Financial NPV and IRR for different timber species

\begin{tabular}{llllll}
\hline & \multicolumn{3}{c}{ NPV } & \multicolumn{1}{c}{ IRR } \\
\cline { 2 - 5 } & \multicolumn{1}{c}{$10 \%$} & \multicolumn{1}{c}{$15 \%$} & \multicolumn{1}{c}{$20 \%$} & \multicolumn{1}{c}{$30 \%$} & \\
\hline Mahogany & $89,533.58$ & $(7,873.45)$ & $(29,690.05)$ & $(32,527.77)$ & $14.18 \%$ \\
Teak & $116,635.63$ & $15,152.51$ & $(21,117.55)$ & $(37,116.22)$ & $16.52 \%$ \\
Eucalyptus & $110,999.96$ & $8,259.82$ & $(27,174.38)$ & $(38,207.28)$ & $15.73 \%$ \\
Jak & $110,991.94$ & $(3,097.51)$ & $(31,728.43)$ & $(38,654.83)$ & $14.72 \%$ \\
Pine & $3,883.12$ & $(33,175.92)$ & $(45,429.960$ & $(47,778.11)$ & $10.34 \%$ \\
Pine-Resin & $32,116.12$ & $(19,700.89)$ & $(38,622.82)$ & $(45,772.04)$ & $12.49 \%$ \\
\hline
\end{tabular}

Brackets indicate negative NPV. 
According to Table 7, when costs are decreased by $10 \%$, NPVs increase and at $15 \%$ discount rate Jak also becomes financially feasible.

Although these NPVs are decreasing as land price increases, Table 8 shows that it is of a very small degree. As mentioned earlier, the land rents used in the analysis represents the existing arrangement of land leasing by FD. But with higher land rent, which can prevail in the future, this situation can change.

Although the land price is increased, according to Table 9, the yield increase fetches more financial benefits than the cost. This will result in an increase in NPVs for all species, implying that the use of more productive lands for forest plantations is attractive. But, above a certain level of land price increment, land price increase will not be justified by the yield increase.

In the economic analysis, when Carbon sequestration and watershed protection benefits are incorporated, it provides very high NPVs. As shown in Table 10, at 6\% social discount rate all the ventures provide very high NPVs. At $6 \%$ discount rate Jak provides the highest economic NPV. When cost increases by $10 \%$ economic NPVs decrease. Results of cost decreases show that at lower costs these ventures are economically more attractive. Recall that this analysis uses the FD norms of allocation of resources for various activities of forestry. If private sector is involved in plantation forestry,

Table 6: $\quad$ Financial analysis at $10 \%$ cost increase at different discount rates

\begin{tabular}{lccccc}
\hline & \multicolumn{2}{c}{ NPV } & \multicolumn{2}{c}{ IRR } \\
\cline { 2 - 5 } & $10 \%$ & $15 \%$ & $20 \%$ & $30 \%$ & \\
\hline Mahogany & $84,334.30$ & $(12,376.39)$ & $(33,710.74)$ & $(35,885.80)$ & $13.78 \%$ \\
Teak & $109,067.65$ & $8,584.62$ & $(26,922.68)$ & $(41,826.750$ & $15.82 \%$ \\
Eucalyptus & $102,705.11$ & $1,961.60$ & $(32,725.24)$ & $(42,694.14)$ & $15.36 \%$ \\
Jak & $104,931.48$ & $(8,559.29)$ & $(36,667.820$ & $(42,792.74)$ & $14.26 \%$ \\
Pine & $(4,384.88)$ & $(40,440.78)$ & $(51,924.48)$ & $(53,151.13)$ & $9.64 \%$ \\
Pine-Resin & $23,848.13$ & $(26,965.75)$ & $(45,117.34)$ & $(51,145.06)$ & $11.76 \%$ \\
\hline
\end{tabular}

Brackets indicate negative NPV. 
130

Table 7: $\quad$ Financial analysis at $10 \%$ cost decrease at different discount rates

\begin{tabular}{llllll}
\hline & \multicolumn{4}{c}{ NPV } & \multicolumn{2}{c}{ IRR } \\
\cline { 2 - 5 } & $10 \%$ & $15 \%$ & $20 \%$ & $30 \%$ & \\
\hline Mahogany & $94,732.87$ & $(3,370.51)$ & $(25,669.35)$ & $(29,169.73)$ & $14.63 \%$ \\
Teak & $124,203.61$ & $21,720.40$ & $(15,312.43)$ & $(32,405.69)$ & $17.31 \%$ \\
Eucalyptus & $120,294.81$ & $14,558.04$ & $(21,623.52)$ & $(33,720.42)$ & $16.58 \%$ \\
Jak & $117,750.40$ & $2,585.63$ & $(26,709.79)$ & $(34,504.02)$ & $15.25 \%$ \\
Pine & $12,151.11$ & $(25,911.05)$ & $(38,935.44)$ & $(42,405.09)$ & $11.11 \%$ \\
Pine-Resin & $40,384.12$ & $(12,436.02)$ & $(32,128.300$ & $(40,399.01)$ & $13.31 \%$ \\
\hline
\end{tabular}

Brackets indicate negative NPV.

Table 8: $\quad$ Financial analysis at $10 \%$ land price increase at different discount rates

\begin{tabular}{llllll}
\hline & \multicolumn{2}{c}{ NPV } & \multicolumn{2}{l}{ IRR } \\
\cline { 2 - 5 } & $10 \%$ & $15 \%$ & $20 \%$ & $30 \%$ & \\
\hline Mahogany & $89,359.40$ & $(7,973.57)$ & $(29,768.11)$ & $(32,577.05)$ & $14.17 \%$ \\
Teak & $116,571.73$ & $15,106.84$ & $(21,152.95)$ & $(37,140.80)$ & $16.51 \%$ \\
Eucalyptus & $110,719.17$ & $8,053.55$ & $(27,333.76)$ & $(38,311.61)$ & $15.92 \%$ \\
Jak & $111,163.14$ & $(3,097.54)$ & $(31,766.97)$ & $(38,697.67)$ & $14.72 \%$ \\
Pine & $12,100.66$ & $(25,947.12)$ & $(38,963.25)$ & $(42,424.16)$ & $11.11 \%$ \\
Jak-Fruit & $173,106.49$ & $20,323.29$ & $(22,401.62)$ & $(36,992.61)$ & $16.66 \%$ \\
Pine-Resin & $31,499.46$ & $(20,141.77)$ & $(38,962.73)$ & $(46,005.19)$ & $12.44 \%$ \\
\hline
\end{tabular}

Brackets indicate negative NPV. 
Table 9: $\quad$ Financial analysis for more productive lands at different discount rates

\begin{tabular}{llllll}
\hline & \multicolumn{4}{c}{ NPV } & \multicolumn{2}{c}{ IRR } \\
\cline { 2 - 5 } & $10 \%$ & $15 \%$ & $20 \%$ & $30 \%$ & \\
\hline Mahogany & 103.512 .04 & $(4.267 .98)$ & $(28,716.42)$ & $(32,471.79)$ & $14.58 \%$ \\
Teak & 135.803 .27 & $23,189.98$ & $(17,459.580$ & $(36,141.89)$ & $17.22 \%$ \\
Eucalyptus & 130.014 .02 & $15,177.76$ & $(24,500.34)$ & $(37,645.48)$ & $16.29 \%$ \\
Jak & 128.706 .70 & $2,176.24$ & $(29,956.83)$ & $(38,418.150$ & $15.19 \%$ \\
Pine & 20.756 .97 & $(21,999.85)$ & $(37,011.730$ & $(41,828.95)$ & $11.82 \%$ \\
Pine-Resin & 42.979 .07 & $(14,846.990$ & $(36,330.49)$ & $(45,209.37)$ & $13.18 \%$ \\
\hline
\end{tabular}

Brackets indicate negative NPV.

Table 10: $\quad$ Results of the economic analysis

\begin{tabular}{|c|c|c|c|c|c|c|}
\hline & \multicolumn{2}{|c|}{ Economic Analysis } & \multirow{2}{*}{$\begin{array}{l}10 \% \text { Cost } \\
\text { Increase }\end{array}$} & \multirow{2}{*}{$\begin{array}{l}10 \% \text { Cost } \\
\text { Decrease }\end{array}$} & \multirow{2}{*}{$\begin{array}{l}10 \% \text { Land } \\
\text { Price } \\
\text { Increase }\end{array}$} & \multirow{2}{*}{$\begin{array}{l}10 \% \\
\text { Productiv } \\
\text {-ty } \\
\text { Increase }\end{array}$} \\
\hline & NPV & IRR & & & & \\
\hline Mahogany & $442,673.16$ & $17.58 \%$ & $429,085.92$ & $452,631.44$ & $449,286.27$ & $492,063.65$ \\
\hline Teak & $562,675.16$ & $19.92 \%$ & $562,198.66$ & $580,218.82$ & $568,939.08$ & $616,053.64$ \\
\hline Eucalyptus & $414,439.82$ & $17.52 \%$ & $402,090.37$ & $426,789.26$ & $409,016.22$ & $450,907.60$ \\
\hline Jak & $156,940.14$ & $20.44 \%$ & $154,070.83$ & $159,809.46$ & $155,559.84$ & $167,952.65$ \\
\hline Pine & $556,119.24$ & $19.53 \%$ & $546,372.30$ & $565,866.18$ & $552,009.83$ & $603,016.22$ \\
\hline Pine-Resin & $266,225.15$ & $21.63 \%$ & $256,728.53$ & $275,721.77$ & $264,080.56$ & $285,664.99$ \\
\hline
\end{tabular}

there can be a drastic cut down of costs. It is clear that at a $10 \%$ land price increase, economic NPVs decrease. Although the land rent is very low for the considered lands, the opportunity cost of land can be high in the future. Therefore, an increase of land values will exert a higher opportunity cost for society in committing the land resource for 
forestry practices. Commitment of more productive lands for forest plantations results in higher returns. But commitment of prime agricultural lands for forest plantations will have a higher opportunity cost of land for society.

Establishment of plantation forests in degraded lands can provide environmental services other than Carbon sequestration and watershed benefits, such as soil structure improvement, micro-climatic functions, flow regulation, regulation of water table etc. Most of these benefits are difficult to quantify and subsequently value due to unavailability of data. However, ignoring these benefits can lead to misallocation of resources. Therefore integration of these benefits into the economic analysis was attempted by assuming a $25 \%$ and a $50 \%$ increase in environmental benefits. The results are shown in Table 11.

When financial and economic analyses are compared, there is a $50 \%$ - 70\% net benefit increase depending on the species. This shows that most of the benefits derived from forest plantations are social benefits and, therefore, not realized by the private individuals. As shown in the financial analysis, most of the forest plantation species are marginally attractive as investment opportunities. However, they are very attractive when the analysis is carried out from the society's point of view. This clearly evident divergence of private and social interest indicates that private individuals may not take initiatives to establish forest plantations without extra incentives from the government. Another question arising from the financial analysis is that although marginal, plantation forestry is profitable. Despite this profitability, private sector involvement in this sector is virtually non-existent. As shown by Senaviratne and Gunatilake (2001) and Gunatilake and Gunaratne (2002) this could be due to excessive regulation on felling and transport of timber. In addition to the extra incentives, it is necessary to create a proper business environment for the private sector involvement in forestry. Revising the existing laws and regulation is a pre-requisite towards that end. 
Table 11: NPV and IRR when environmental benefits increase by $25 \%$ and $50 \%$

\begin{tabular}{lcccc}
\hline & \multicolumn{2}{c}{$\begin{array}{c}25 \% \text { Environmental benefit } \\
\text { increase }\end{array}$} & \multicolumn{2}{c}{$\begin{array}{c}\text { Environmental benefit } \\
\text { increase }\end{array}$} \\
\cline { 2 - 5 } & NPV & IRR & NPV & IRR \\
\hline Mahogany & $442,673.16$ & $17.58 \%$ & $442,673.16$ & $17.58 \%$ \\
Teak & $562,675.16$ & $19.92 \%$ & $562,675.16$ & $19.92 \%$ \\
Eucalyptus & $425,497.45$ & $17.38 \%$ & $436,555.08$ & $17.52 \%$ \\
Pine & $188,424.09$ & $18.53 \%$ & $219,908.04$ & $20.44 \%$ \\
Jak & $592,000.42$ & $18.65 \%$ & $627,881.60$ & $19.53 \%$ \\
Pine-resin & $309,561.92$ & $19.93 \%$ & $338,898.68$ & $21.63 \%$ \\
\hline
\end{tabular}

If intensive plantation forests are to remove the pressure to cut existing natural forests that are important for biological conservation, they must be managed in a way that is sound for the local environment. The sites chosen for intensive plantations must not be habitats crucial to biological conservation. They should be physically managed in such a way as to ensure adequate environmental protection. Erosion rates need to be managed so that they remain as close to natural rates as possible. Ecologically sound methods of pest and fertilizer management should be implemented. Forestry is a very sensitive issue where public concerns play an important role in decision making. Therefore, plantation managers must select species carefully to suit social and cultural norms.

\section{Conclusions and Policy Implications}

The results imply that there is a clear divergence between financial and economic returns for forest plantations. Around 50\% to $70 \%$ of the benefits derived from plantation forests are environmental benefits. They are realized by society but not by the investor. Therefore, government interventions are necessary to get private sector involvement in forest plantations. Revision of existing regulations is a precondition for creating a suitable business environment for plantation forestry. The feasibility of providing some assistance and subsidies to develop the private sector forest plantations has to be assessed in detail. Credit facilities, provision of technical assistance, planting 
materials and land are some of the possible areas of assistance.

\section{Reference}

Abayasiri, S. and D.M.S.H.K. Ranasinghe, (2000). The Contribution of Forest Plantations (Teak) in Sri Lanka in Acting as a Carbon Sink to Reduce Greenhouse Gases in the Atmosphere: Proceedings of the Sixth Annual Forestry and Environment Symposium 2000, University of Sri Jayawardenapura, Sri Lanka.

Abeygunawardena, P., M.B. Lohani, D.W. Bromley, and R.C. Barba, eds. (1999). Environment and Economics in Project Management: Ten Asian Cases, ADB Publication.

Gunatilake, H.M. (1998). Land Reclamation Project in Muthurajawela Coastal Wetland; Economic and Ecological Issues. Sri Lankan Journal of Agricultural Science, 35:94-111.

Gunatilake, H.M. and C. Gopalakrishnan (1999). The Economics of Reservoir Sedimentation: A Case Study of Mahaweli Reservoirs in Sri Lanka. Water Resource Development, 5(4):511-526.
Gunatilake, H.M. and L.H.P. Gunaratne (2002). Policy Options for Protecting Natural Forests in Sri Lanka. A Report Prepared for Economy and Environment Program for Southeast Asia.

Gunatilake, H.M. and E.R.N. Gunawardena (2000). An Assessment of On-Site and Off-Site Cost of Soil Erosion in the Upper Mahaweli Watershed. Sri Lankan Journal of Agricultural Sciences, 37:130-134.

Hufschmidt, M. and J.A. Dixon, eds. (1986). Economic Valuation Techniques for the Environment; A Case Study Work Book. London: John Hopkins University Press.

Ruitenbeek, J. (1989). Rational Exploitations: Economic Criteria and Indicators for Sustainable Management of Tropical Forests, CIFOR

Senaviratne, J. and H.M. Gunatilake (2001). Can Legislative Measures Protect Natural Forests in Sri Lanka? A Report Prepared for the Department of Planning, Colombo, Sri Lanka. 
Ministry of Forestry and Ministry of Policy Planning and Environment (MFE) (1995). Implementation (1999). Forestry Sector Master Plan, Statistical Abstract 1999, Ministry of Forestry and Ministry of Policy Planning Environment, Battaramulla, Sri and Implementation, Sri Lanka. Lanka. 